\title{
River valleys as ecological corridors - structure, function and importance in the conservation of natural resources
}

\author{
Jarosław Tomasz Czochański, Paweł Wiśniewski* \\ University of Gdańsk, Faculty of Oceanography and Geography, Institute of Geography, \\ Department of Physical Geography and Environmental Management, \\ J. Bażyńskiego 4 St, 80-309 Gdańsk, Poland, \\ *e-mail: p.wisniewski@ug.edu.pl
}

Received: November 2017 / Accepted: 27 February 2018

\begin{abstract}
The paper presents the concept of an ecological corridor system developed for spatial planning based on the case of the Pomerania Province. More attention was paid to the corridors along watercourses and river valleys. The study included e.g. spatial relationships between the proposed network of regional eco-corridors and the national network as well as areas of protected nature areas, including Natura 2000 sites. The main threats to the valley corridors in the area were identified. Depending on the level of impact and the geographical range, three different land corridors were distinguished: supraregional, regional and subregional. Due to the landscape and nature diversity, spatial distribution of physico-geographical units, terrain and river valleys, almost all communes and districts of the Pomerania Province have appropriate conditions to perform the functions of ecological corridors of various ranks. In some communes, they account for more than $50 \%$ of the total area and $28 \%$ of the province's area, and a significant part of them are valley ecosystems. The aim of the paper is to document the role of river valleys in shaping the conditions of spatial connectivity of ecosystems and to indicate their significance for spatial planning processes.
\end{abstract}

Key words: river valley, ecological corridor, spatial planning, Pomerania Province.

\section{Introduction}

In accordance with the Nature Conservation Act of 16 April 2004 (Ustawa... 2018), the ecological corridor is defined as an area allowing the migration of plants, animals or fungi. However, it is a definition narrowed to the biological phenomenon of species migration, eliminating the full, comprehensive understanding of the importance of ecological corridors and limiting the opportunities and the pursuit of their real behavior. Ecological corridors are of landscape, environmental and protective significance. They help in the movement of matter and energy, play an enormous role for the habitat, and shape the space and conditions of human life and the conditions of economic activity (Forman \& Godron, 1981; Beier \& Noss, 1998; Wojciechowski, 2004; Romanowski, 2007; Rozenau-Ry- bowicz \& Baranowska-Janota, 2007; Christie \& Knowles, 2015). They are a form of ordering spatial relationships in planning and land development.

Walker and Craighead (1997) define an ecological corridor as a pathway for migration of species of high spatial requirements, spread of plants, genetic exchange, population movement in response to natural environmental changes or disturbances as well as the replenishment of local populations of endangered species by individuals from other areas. Pchałek et al. (2011), on the other hand, define an ecological corridor as a route that enables migration and dispersion of plants, animals, fungi, protists and diasporas between patches of their habitats, and which includes linear, nonlinear, bandar or area-dependent, continuous or discontinuous, natural, semi-natural or anthropogenic, biotic or abiotic structural elements of the natural environment, 
including airspace. This is an interesting attempt to combine approaches to the protection of ecological corridors and ecological connectivity from the functional (ensuring the continuity of the population of organisms) and structural (ensuring the cohesion of the landscape structures) point of view.

In light of the above mentioned features and functions of ecological corridors, the river valleys are their classic and basic forms. They have a set of natural features, often not co-occurring in other types of landscape. They are characterized by the availability of surface water and moisture, the relative naturalness and diversity of habitats, the relatively weak anthropopressure and the durability of agroecosystems. They are the most durable forms of landscape structure, as well as natural links between habitats, natural objects, areas and regions.

They allow the movement of matter and energy in the environment and, alongside, the geochemical and biological components. They ensure the spatial connectivity between habitats and allow the migration of plants, animals or fungi. Natural values of river valleys and their role in the transfer of diaspora and organisms make them an important element of the Natura 2000 network. In the valley corridors, as hardly in any other type of ecological corridors, their systemic character (multicomponent and multifunctional ecosystem) is revealed. These are landscape forms, relatively durable, most complex and dynamically variable. Andrejczuk (2007) draws attention to the particular features of river valleys in geoecological and geosystemic contexts. According to Pietrzak (2010), the valley - as an ecological corridor - is primarily a spatial landscape structure, which according to the assumptions of ecology of the landscape is characterized by spatial characteristics (chorostructure), functional characteristics (etostructure) and time variability (chronostructure).

For a number of years now, there has been a clear interest in the linking of the river valleys to the network of ecological connectivities (Brandt, 1995; Gallé et al., 1995; Dombrowski et al., 2002; Chmielewski, 2004; Jongman \& Kamphorst, 2002; Kałamucka, 2007; Romanowski, 2007). Considering these issues together seems very promising, because, as a subject of research, they play a vital role in natural sciences and spatial planning. Moreover, they significantly shape the conditions of land use and habitable space for humans. River valleys, considered as a basic element of spatial communication, are, in addition to forest areas, key elements in the European concepts of ecological corridor (e.g. The Pan European Ecological Network, Trans-European Wildlife Network, networks in France, Netherlands, Germany, Austria and the Czech Republic). River valleys have also been included in the national ecological network ECONET - Poland (Liro, 1995), in the project of ecological corridors linking the European network Natura 2000 in Poland, prepared under the commission of the Ministry of Environment (Jędrzejewski et al., 2005), and with the vision of a coherent, hierarchical network of nodes and ecological corridors, as a part of the continental network, included in the National Spatial Development Concept 2030. River valleys as corridors should also become important elements of regional and local ecological networks developed for spatial planning purposes. Their inclusion in the planning documents at the various levels of the local government should be an important element for achieving the aims and principles of nature conservation, while at the same time protecting the river valleys and their large biocenotic and landscape diversity.

The aim of the article is to present the concept of the ecological corridor system, developed for the purposes of spatial planning in the Pomerania Province - paying a closer attention to the corridors along the watercourses and river valleys. The study included, for instance, the spatial relationships between the proposed ecological corridor network and the national network as well as areas of nature conservation, including Natura 2000 sites. Examples of threats to spatial continuity and the naturalness of the proposed corridors were also indicated.

\section{Materials and methods}

Pomerania Province, as one of the first in Poland, planned a network of ecological links and took it into account in its planning documents (Czochański, 2004). In order to fulfill the principles of sustainable development in the planning and spatial economy of the province, the assumption of preserving and shaping the ecological structure of the region (based on existing or reconstructable spatial relationships of natural areas) has been adopted as a basis for pro-ecological activities and preservation of favorable living conditions for the inhabitants. This has led to the delimitation of the network of ecological links of sub-local importance, based on the general assumptions of the patches and corridors. Already by the year 2000, the first project of a network of ecological corridors was established, which, two years later, was included in the first spatial development plan of the Pomerania Province. The basis for the work was presented by Przewoźniak (2001), further elaborated and spatially specified by Czochański (2002). During the studies, the spatial interrelationship of nature structures, proposed by Chmielewski (1988), was adopted. In this way, clear corridors and ecological patches were distinguished. They included, for example, uninterrupted by anthropogenic development river valleys along with their surroundings. In 2013, in the Pomerania Province, the study of ecological corridors got started. By 2014 the Pomeranian ecological network concept for spatial planning was presented (Bezubik et al., 2014). It was the basis for the new spatial development plan of the Pomerania Province (Bezubik et al., 2016) in the scope of shaping and 
protecting the ecological cohesion of the region. The proposal of a network of ecological corridors presented in this paper is a more detailed and corrected description of the corridors boundaries presented in the study by Bezubik et al. (2014). However, the basic spatial extent of the corridors have not been changed, and the scale of the figures does not allow their comparison with the models included in the referenced study.

The detailed boundaries of ecological corridors were determined primarily along the edges of the extent of ecosystems with preserved natural features (including forest boundaries, tree belts, meadows) and, additionally, along the edges of erosive terrain elements (e.g. erosive edges of slopes of valleys). The rank of corridors results from the spatial relations described below with other corridors and elements of the natural structure of the region.

Several factors have been used to designate the ecological corridors in order to determine their optimal range, location and rank. For this purpose the following aspects were analyzed:

- natural and landscape structure of the region (e.g. spatial distribution of forest communities, peatbogs, marsh, grasslands and lakes);

- occurrence of river valleys, their parameters and degree of anthropogenic transformation;

- actual spatial distribution of forest animals (on the basis of inventory of hunting circles) and protected species (based on inventory of hunting circles, data from the Regional Directorate of the State Forests and Regional Directorate for Environmental Protection);

- actual, identified migration routes for forest animals (based on information obtained from forest districts and scientific communities);

- size and spatial distribution of road collisions with animals (based on data from the General Directorate for National Roads and Motorways and the Regional Road Administration);

- occurrence of natural protected areas (including Natura 2000 sites, national and landscape parks as well as nature reserves and protected landscape areas) as a means of partially securing the existence of a corridor in such area.

Designing a network of ecological corridors also included:

- earlier concepts of the ecological network of the province;

- the concept of a network of ecological corridors connecting the European network Natura 2000 in Poland (Jędrzejewski et al., 2005);

- results of research and analysis on functional issues related to the ability of species to move in space and visualizing the real spatial distribution of animal population in the province;
- the role of corridors, as spatial connectors between ecological patches and areas under the legal environmental protection;

- criterion of minimal space, necessary to preserve and maintain ecological function.

Due to its functional character and the use, for the purpose of migration and dispersions, groups of species, migration corridors of terrestrial species, flights of bird and bat species and migratory corridors of aquatic species were identified. The space of the migratory routes as well as habitats of herpetofauna and lepidopterofauna were not included. The extent of their relocation is related to local natural structures, which are impossible to record and designate from analysis and regional studies.

Due to the nature of the environment, the terrain and the coverage of the area the following corridors were identified:

- valley corridors - developed along watercourses and river valleys, with inland water bodies (river beds and lakes), with agricultural land (with significant predominance of grasslands), accompanied by bushes and coastal trees and trees at the edge of slopes of valleys;

- forest corridors with predominant cover of forest habitats, of a continuous nature;

- forest corridors with relatively small patches of a discontinuous nature ("stepping stones") forming a series of neighboring islands of forest ecosystems;

- field afforestation and roadside tree corridors (complementary to other ecological routes);

- non-forest corridors - beyond-valley strips of pastures with small bushes and trees;

- habitats of water reservoirs, coastal waters and wetlands, spatially discontinuous, in the areas of seasonal migration of birds.

Due to the functional role of the corridor in the structure of the natural environment and its spatial extent, the following corridors were identified:

- supraregional corridors - providing spatial connectivity of natural European and national structures as well as neighboring physicogeographical regions of the province, subprovinces and macroregions;

- regional corridors - providing spatial connectivity of natural structures within physicogeographical macroregions and mesoregions and providing connectivity between supraregional structures;

- subregional corridors - providing spatial connectivity of natural structures within mesoregions and providing connectivity between regional and supraregional structures of corridors. 


\section{Results and discussion}

Within the territory of Pomerania Province, ecological corridors with a total surface area of $5150 \mathrm{~km}^{2}$, were outlined. This represents $28 \%$ of the total land area. The structure of land use, in the outlined ecological corridors, is dominated by forests $\left(3250 \mathrm{~km}^{2}\right)$ and agricultural land (1500 $\mathrm{km}^{2}$ ), occupying, respectively, $63 \%$ and $29 \%$ of the corridor area. Surface water in the corridors covers $350 \mathrm{~km}^{2}$ (7\% of the corridor area) and built-up areas and other forms of land cover $70 \mathrm{~km}^{2}$ ( $1 \%$ of the area) (Fig. 1). The dominance of forestry land with surface water and agricultural land, with prevalence of grassland, is a guarantee of the durability of corridors, provided that the attempts to locate residential areas in attractive landscapes of forests and waters are not successful (Bezubik et al., 2014).

Landscape and natural diversity, spatial distribution of physicogeographical units, terrain and river valleys create the conditions that in almost all communes and districts of the Pomerania Province there are areas, which can perform the functions of ecological corridors of varying ranks. The specific location of ecological corridors, especially in the vicinity of the sea coast, in the stretch of land of the Hel Peninsula and the Vistula Spit as well as within the river valleys of the largest rivers of Pomerania, results in the fact that, in the area of 19 communes (out of 140 in the province) ecological corridors occupy more than $50 \%$ (Fig. 2). Only in 13 communes (mainly urban) were no ecological corridors outlined.

The corridors of supraregional and regional ranks play a leading role in preserving the spatial connectivity of ecological structures (Bezubik et al., 2014). As a result of the delimitation of terrestrial ecological corridors, within the Pomerania Province, 7 spatial structures of supraregional and regional corridor ranks were outlined. They play an important connectivity role for natural and valuable natural as well as protected areas at national and supranational levels. The total area of these corridors within the province (excluding the water area of the coastal zone of the Vistula Lagoon) is approx. $3000 \mathrm{~km}^{2}$, which accounts for $16.4 \%$ of the province's area. These are the following corridors: Nadzalewowy (along the Vistula Spit and its coastline, further covering the area of less than $47 \mathrm{~km}^{2}$ of coastal waters of the Vistula Lagoon to $2 \mathrm{~m}$ isobath), Nadmorski (along the Hel Peninsula and the Baltic Sea Coast), Vistula River Valley, Słupia and Wda Valley, Gwda Valley, sequence of valleys of Wieprza - Studnica - Brda and

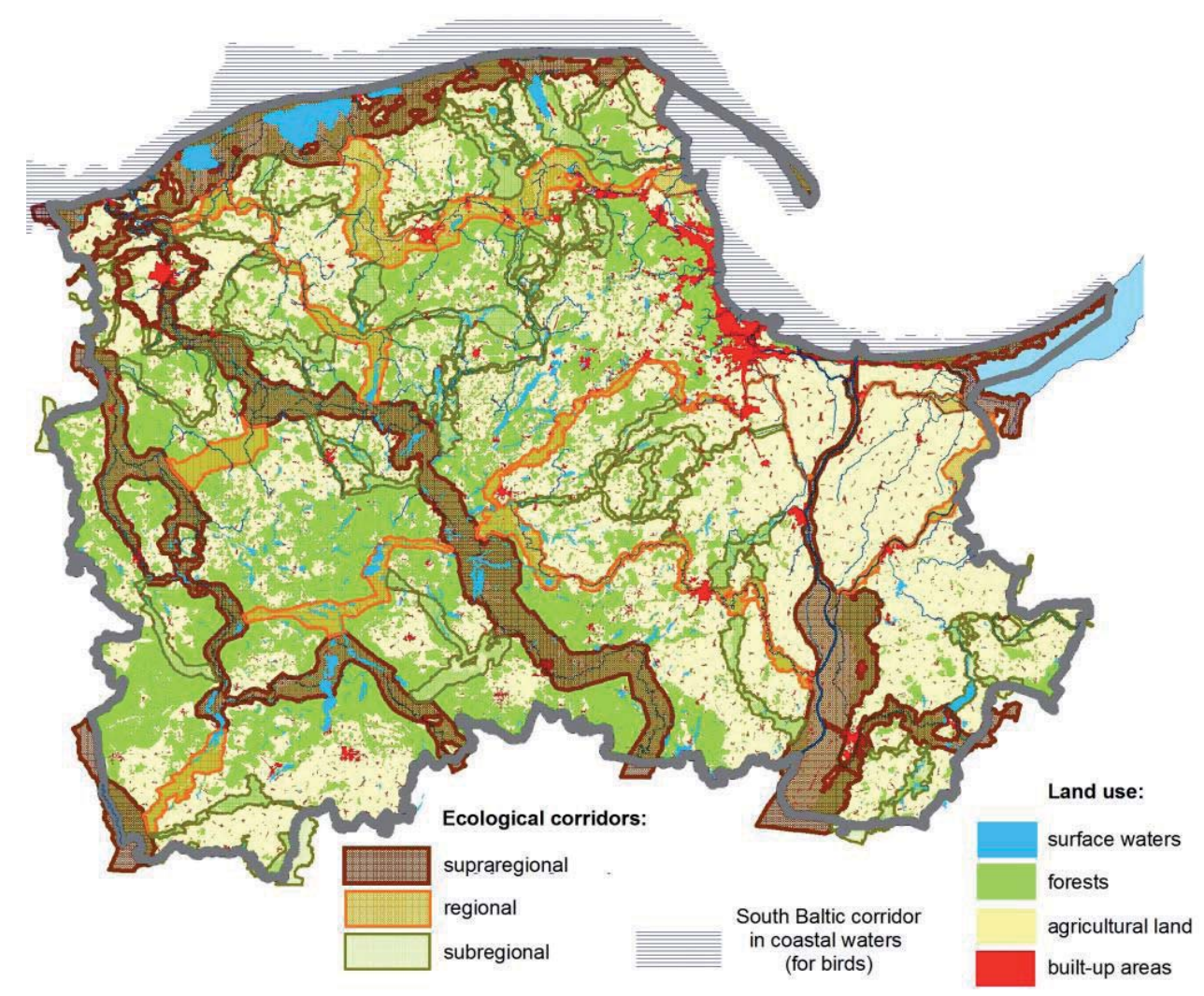

Figure 1. The network of ecological corridors in Pomerania Province against land use, according to Bezubik et al. (2014), modified 
Liwa Valley. The area of corridors of regional importance within the province is $1,150 \mathrm{~km}^{2}$, which accounts for $6.3 \%$ of its area. These corridors mainly include geomorphological structures of river valleys of the largest coastal rivers: proglacial stream valley of Reda-Łeba, Łupawa River Valley (together with a link to Słupia), Zbrzyca Valley, Radunia and Motława Valley, Wierzyca Valley, Nogat Valley, Szkarpawa Valley, Szczyra Valley and the linking forest belt between Słupia and Wieprza (Forest Trzebieliński Corridor). In total, the system of ecological corridors of the supraregional and regional level covers an area of about $4,150 \mathrm{~km}^{2}$ (22.6\% of the province), $58 \%$ of which is occupied by forests, $33 \%$ by agricultural land, $7 \%$ by surface water, $2 \%$ by built-in areas and other forms of land cover.

In total over $66 \%$ of the area of supraregional corridors and $55 \%$ of the area of regional corridors are currently under the nature protection acts. Within the boundaries of national parks and nature reserves there are about $10 \%$ of the area of supraregional corridors and $0.01 \%$ of the area of corridors in the regional rank. Within Natura 2000 area, it is $50 \%$ and $26 \%$ respectively, within the boundaries of landscape parks $-20 \%$ and $8 \%$, within areas of protected landscape $-30 \%$ and $40 \%$. Apart from the forms of nature conservation, there are less than $34 \%$ of the area of supraregional corridors and $45 \%$ of the area of regional corridors. Protective measures should be planned for these areas in order to preserve existing forms of use and continuity of the elements of natural land cover. It is necessary to take into account the course of corridors in spatial planning documents as a basis for guaranteeing their preservation, defining the rules of using these areas, which do not affect the permanence of their existence. At the same time, measures should be taken in order to establish protected landscape areas within the area of unprotected corridors as a statutory form of their protection.

Supraregional and regional network is complemented by terrestrial subregional corridors. They contribute to the strengthening of spatial connectivity and the linking forces of larger natural and protected areas. They cover a total of $1340 \mathrm{~km}^{2}(7.3 \%)$ of the area of the Pomerania Province, providing relatively narrow and short links between elements of the network of higher rank corridors and ecological forest patches. They cover, mostly, the river valleys of smaller lakeland watercourses, forest areas and smaller clumps of trees. Forests cover up to $70 \%$ of their surface area, surface water $-5 \%$, built-up areas $-0.5 \%$. Approximately $55 \%$ of the area of subregional corridors lies within the boundaries of already established natural

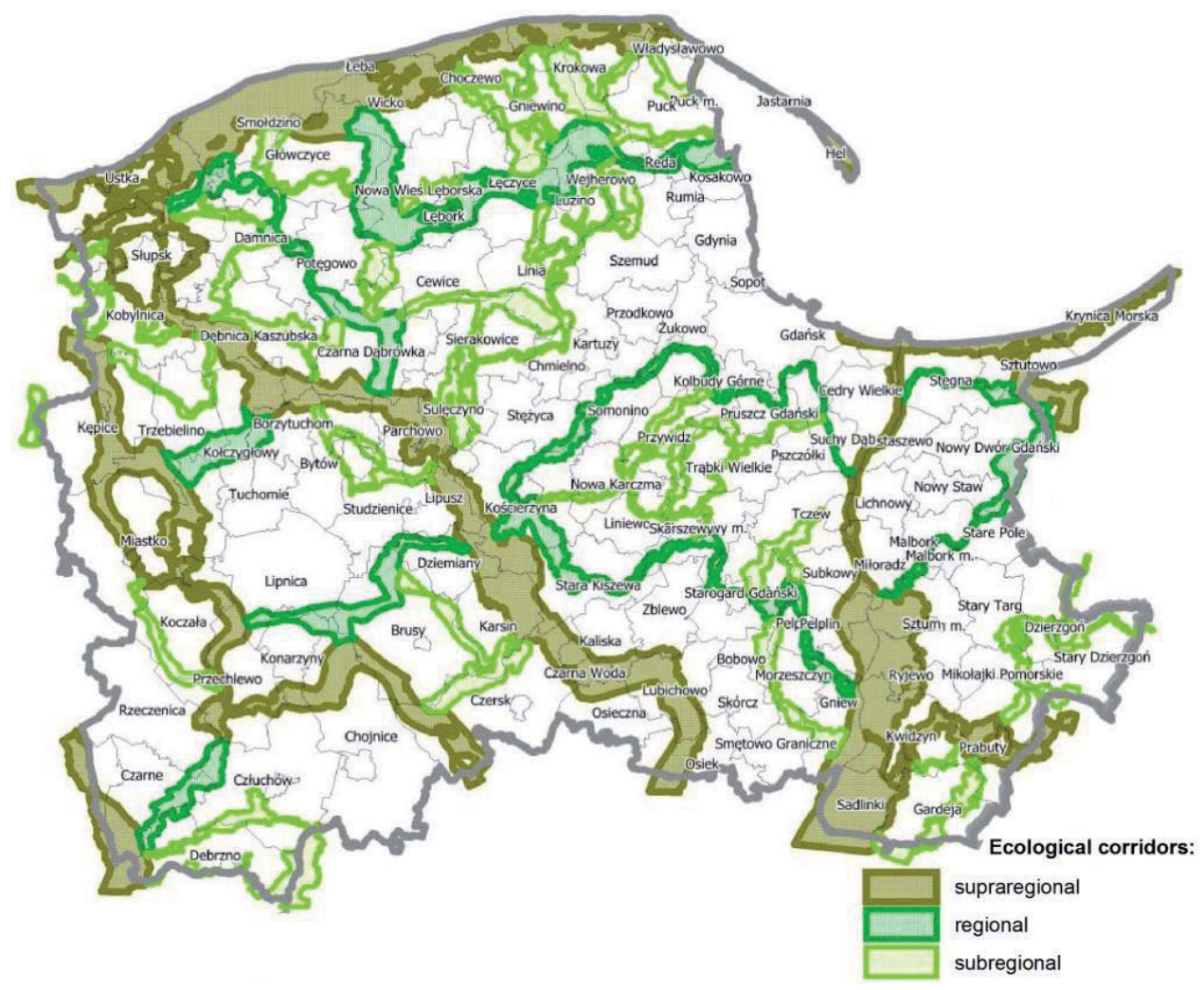

Figure 2. Ecological corridors against the administrative division of the Pomerania Province, according to Bezubik et al. (2014), modified 
protected areas (Natura 2000 sites, landscape parks and landscape protection areas).

Because of the scope of the study, the methodological basis (based on the landscape structure of the region and the occurrence of selected species) as well as the objective (which is to outline the regional network of ecological corridors for the purposes of regional spatial planning), the presented concept did not determine local objects connecting the fragments of the designed regional network with small natural structures. This does not mean that the local ecological corridors (above all the tree belts and river valleys) are not relevant for the functioning of the whole environment. They often play an essential role in preserving local populations of different species and habitats, providing space for organisms to migrate at shorter distances. These corridors should be outlined in the planning documents at the local level - in ecophysiographic studies, studies of conditions and directions of spatial management of communes and local spatial development plans, based on thorough knowledge of local spatial conditions (Bezubik et al., 2014).

All supraregional ecological corridors defined in the presented concept fits well into the natural structure of the northern national corridor and in the structures of neighbouring provinces. They constitute a direct, very important link in the chain of ecological relationships, enabling the linkage of ecosystems, which are environmentally valuable in northern Poland. The outlined structures of national level corridors bind the Pomerania Province with all four neighboring provinces. Some regional corridors, and even subregional ones, play a similar role. Due to the fact that the corridor of Vistula River Valley passes through the area of the Pomerania Province, it is possible to assume that the direct connectivity with Southern Poland be preserved. The extent and the course of ecological corridors guarantees, at the same time, the spatial connection of the most valuable and legally protected areas of the Pomerania Province and neighboring legally protected areas - Natura 2000 sites, national parks, landscape parks, protected landscape areas

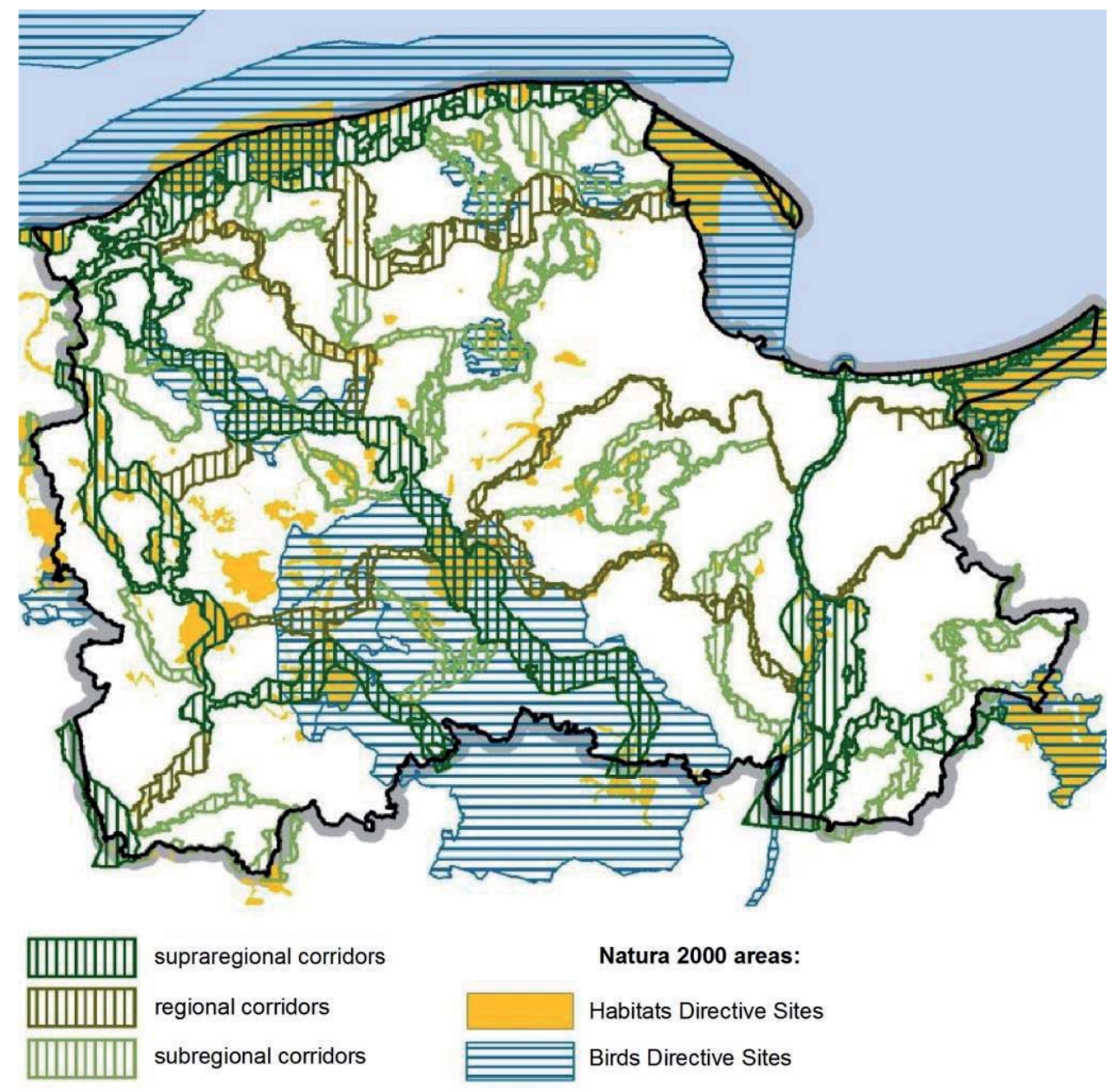

Figure 3. Ecological corridors against the Natura 2000 network in the Pomerania Province, according to Bezubik et al. (2014), modified 
and nature reserves. The sequences of ecological corridors ensure the connectivity of all areas of special protection of birds within the boundaries of the province and in the Baltic coastal zone. The most important role here is played by the sequence of two corridors: Nadmorski and Słupia and Wda valleys. The corridor system also provides spatial connectivity to a number of sites, which are of Site of Community Importance (SCI), numerously occurring in the Pomerania Province and in the adjacent sea zone (Fig. 3). The sequences of corridors also provide connectivity of almost all protected areas in the form of national parks, nature reserves, landscape parks and protected landscape areas (Fig. 4).

There are 7 supraregional corridors outlined within the province, out of which 5 are valley corridors including the valleys of 8 rivers: Wisła, Słupia, Wda, Gwda, Wieprza, Studnica, Brda and Liwa. Out of 11 regional corridors, 10 are valley corridors, covering 12 rivers: Reda, Łeba, Łupawa, Słupia, Zbrzyca, Radunia, Motława, Wierzyca,
Nogat, Szkarpawa, Szczyra and Grabowa. All of the 36 subregional corridors have the character of valley corridors. Altogether, within the supraregional corridors there are 127 sections of various rivers, 80 sections in the regional corridors and 105 sections in the subregional corridors (Fig. 5).

According to Chmielewski (2004), river valleys - due to their transit function - are in many planning documents almost automatically outlined as ecological corridors, without going into the actual ecological processes that occur in them. According to this author, while outlining ecological corridors in spatial planning, it is essential to remember that river valleys can be considered as main, multi-species corridors in the landscape if they preserved their natural or semi-natural character, are not occupied by development and communication routes, do not lead unduly polluted waters, and are not crossed by a number of barrier structures. Moderately transformed river valleys can be migratory routes only for a narrow group of species, and

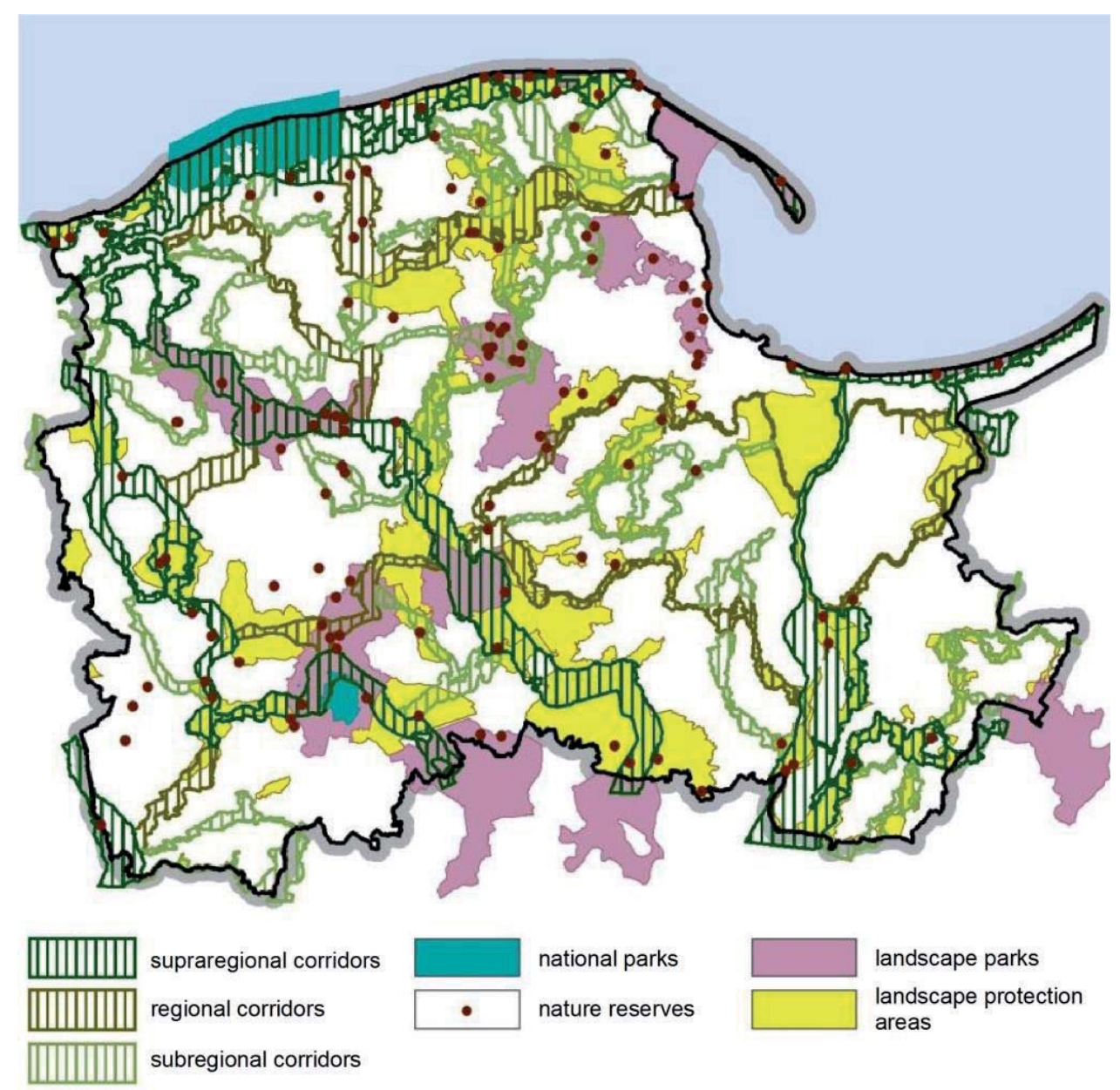

Figure 4. Ecological corridors against the national network of protected areas in the Pomerania Province, according to Bezubik et al. (2014), modified 
heavily transformed and contaminated river valleys should be viewed rather as contamination zones, ecological barriers and pathways of pollution movement in the landscape.

Many of the valley forms, especially of larger sizes, undergo increasing transformation as a result of their development. Not only does it cover the riverbed itself (such as flood protection and related infrastructural investments, regulation for navigation, energy use and accompanying dams, damping levels and water stages) but also the bottom of the valley (melioration, earthworks and development in urban areas) as well as the valley slopes and surroundings of their upper edges. These changes are mainly related to changes in the form of land use and valley development. All this limits the spatial continuity and coherence of the watercourses and entire valley systems. Many river valleys are interrupted today by infrastructure and development, functioning as spatial objects only in selected sections. From the point of view of the sustainability of ecological links, where the valley should function as an ecological corridor, such changes are not only undesirable, but often completely eliminate the connectivity of natural ecosystems. The synthesis of such anthropogenic transformations related to the management of the landscape of river valleys was presented in Plit's paper $(2007,2008)$.
The durability of the valley as a corridor is determined by the relationship and durability of many features and components (geomorphological, hydrological, biotic). However, in the case of tree strips, only one biological trait - the existence of a community or vegetation belt decides their durability. Thus the anthropogenic transformation or extreme annihilation of such a one-trait corridor is potentially much easier than the corridor formed by a complex of many polygenetic features and components. The analysis of spatial structures in various areas of the Pomerania Province showed the existence of many well-preserved natural valleys or fragments of river valleys, often meandering watercourses with floodplains and tree-lined slopes, not yet managed and intensively utilized. The greatest threat to the spatial continuity and naturalness of such valley corridors in the Pomerania Province is their development. Contrary to environmental conditions and against the rules of safety, a permanent infrastructure in the form of built-up areas (including housing) and communication have been introduced into the bottoms of river valleys (often in the floodplain areas). This is because local government authorities and investors underestimate the physiographic conditions of the location of the buildings and the lack of legal solutions for the protection of ecologi-

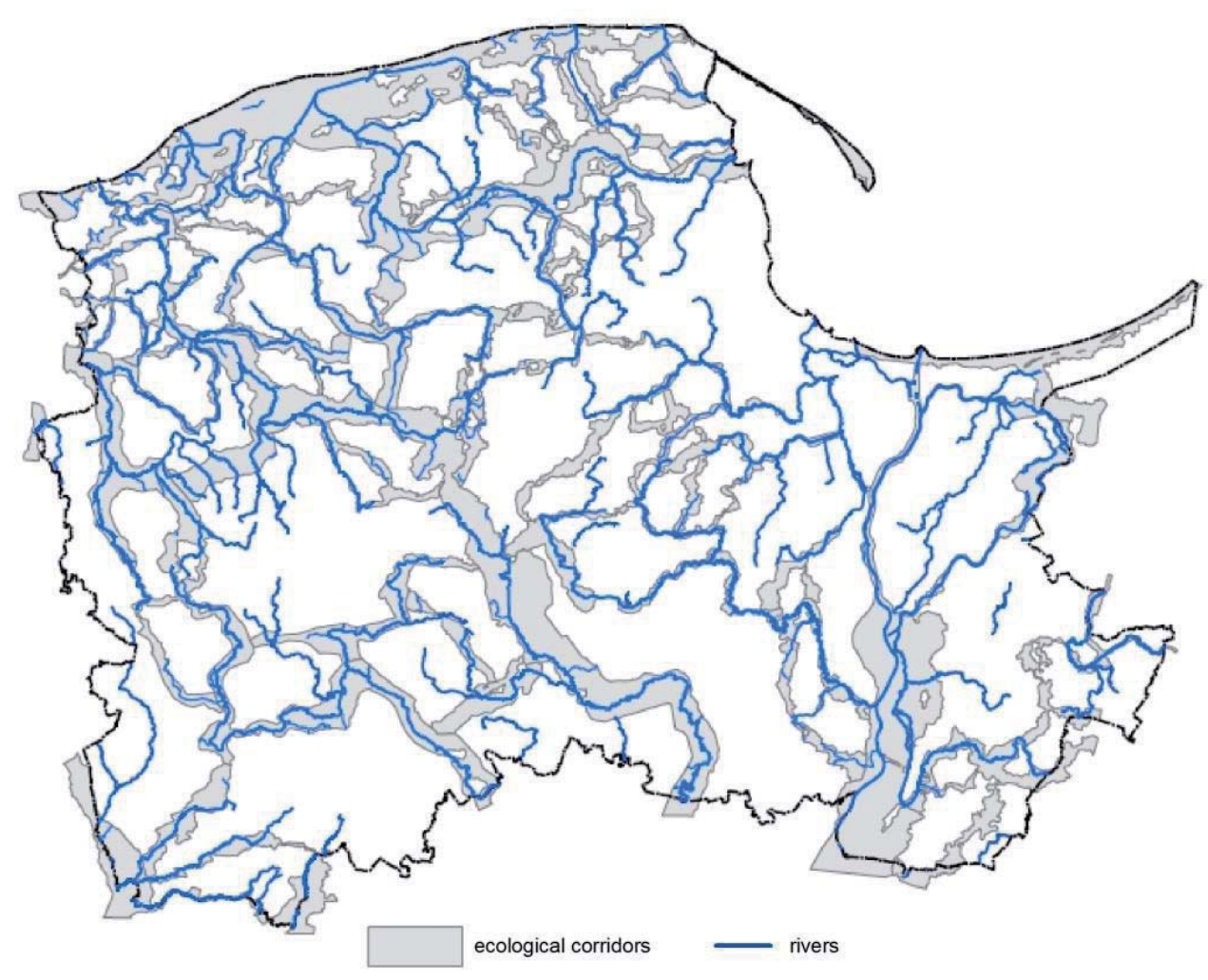

Figure 5. Ecological corridors against the river network in the Pomerania Province, according to Bezubik et al. (2014), modified 
cal corridors. A classic example of such a situation is the location of residential settlements in the proglacial stream valley of Reda-Łeba, which is a regional ecological corridor (indicated in the Pomeranian spatial development plan) and the migration zone of birds and bats from the Gdańsk Bay towards inland (Fig. 6). Such actions often permanently eliminate the possibility of the functioning of an ecological corridor and preserving spatial connectivity between important island ecosystems or between protected areas. In many cases, within the boundaries of built-up areas, the spatial continuity of the river valley corridor is limited to the riverbed and its immediate shore zone, which can be observed in the valleys of the rivers Radunia and Stupia.

\section{Conclusions}

1. Ecological corridors guarantee the preservation of connectivity, migration and dispersion of species and thus preservation of their populations and biodiversity. In most of the proposed European ecological corridor networks, river valleys - alongside forest areas - play a key role. They guarantee spatial connectivity, are comprehensive and relatively permanent landscape units and not part of spatial areas, and should be considered holistically rather than fragmentary as individual sections.
2. In Pomerania Province river valleys play a leading role in shaping the spatial continuity of terrestrial ecosystems. Out of a total of 54 ecological corridors of national, regional and subregional status, as many as 51 are valley corridors. They constitute a direct, very important link in the chain of ecological relationships, enabling the linkage of natural and environmentally valuable ecosystems, which are protected at national and transnational levels.

3. The greatest threat to the spatial continuity and naturalness of the valley corridors in the studied area is their development and buildings. Contrary to environmental conditions and against the rules of safety, a permanent infrastructure in the form of built-up areas (including housing) and communication have been introduced into the bottoms of river valleys (often in the floodplain areas).

4. Outlining ecological corridors in the administrative area of the province and guaranteeing their sustainability, for example, by including them in the spatial planning documents or establishing protected landscape areas (as defined by the statutory definition of this form of nature conservation), is a fundamental guarantee for preserving the existence of valuable ecosystems and ecological connectivity to the natural environment. This is the basis for the migration of species, preservation of biodiversity and landscape.

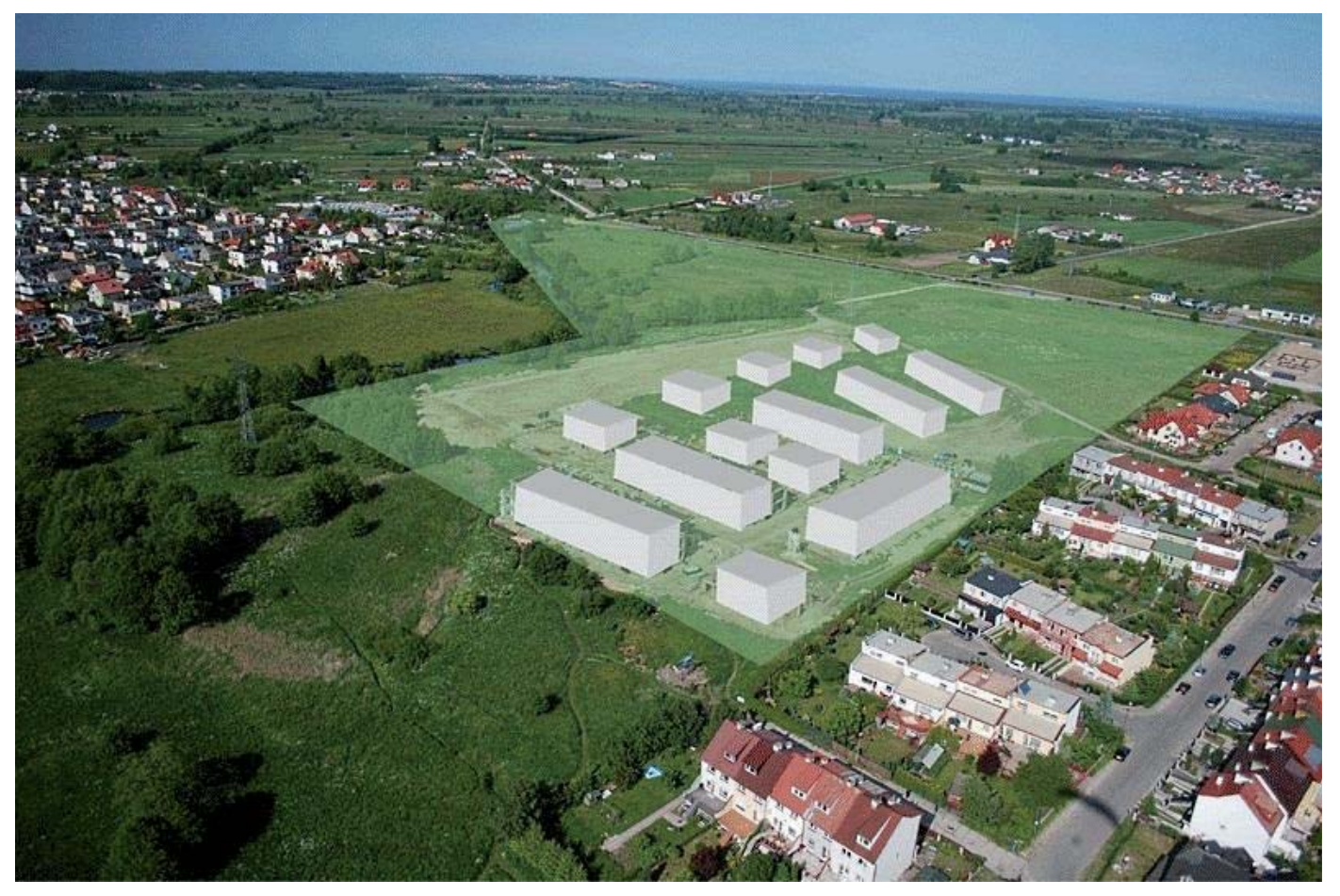

Figure 6. Architectural visualization of housing estate in the proglacial stream valley of Reda- $€$ eba (source: materials published by the investor) 


\section{References}

Andrejczuk W., 2007, Krajobrazy dolin rzecznych [Landscapes of river valleys]. Prace Komisji Krajobrazu Kulturowego PTG 7: 9-27.

Beier P. \& Noss R.F., 1998, Do Habitat Corridors Provide Connectivity? Conservation Biology 12(6): 1241-152.

Bezubik K., Czochański J.T., Golędzinowska A., Hałuzo M., Kubicz G., Łoziak A., Mazur A., Mazurkiewicz B., Obracht-Prondzyńska H., Olech J., Pępek B., Pomierski E., Radziszewska G., Rekowska J., Radzikowski M., Richert M., Rudzińska A., Siłkowska I. \& ŻebiałowiczŁach A., 2016, Plan zagospodarowania przestrzennego województwa pomorskiego 2030 [Spatial development plan of the Pomerania Province 2030]. Pomorskie Biuro Planowania Regionalnego, Gdańsk.

Bezubik K., Czochański J.T., Hałuzo M., Mazurkiewicz B., Pietruszewski J., Pomierski E., Radziszewska G., Rekowska J., Rudzińska A., Siłkowska I. \& Wojcieszyk K., 2014, Koncepcja sieci ekologicznej województwa pomorskiego dla potrzeb planowania przestrzennego [The concept of ecological network in the Pomerania Province for the needs of spatial planning]. Pomorskie Biuro Planowania Regionalnego, Gdańsk.

Brandt J., 1995, Ecological networks in Danish planning. Landschap 12: 63-76.

Chmielewski T.J., 1988, O strefowo-pasmowo-węzłowej strukturze układów ponadekosystemowych [The zoneband-node structure of systems over ecosystems]. Wiadomości Ekologiczne 34(2): 165-185.

Chmielewski T.J., 2004, Doliny rzeczne jako strefy akumulacji skażeń i korytarze przemieszczania się zanieczyszczeń w krajobrazie [River Valleys as a zones of acumulation of environmental contamination and the corridors of pollutant movement in landscape], [in:] A. Cieszewska (ed.), Płaty i korytarze jako elementy struktury krajobrazu - możliwości i ograniczenia koncepcji [Patches and corridors as a landscape elements adventages and limitations of the concept]. Problemy Ekologii Krajobrazu, SGGW, Warszawa: 176-177.

Christie M.R. \& Knowles L.L., 2015, Habitat corridors facilitate genetic resilience irrespective of species dispersal abilities or population sizes. Evolutionary Applications 8(5): 454-463.

Czochański J.T., 2002, Ekologiczne podstawy rozwoju i bezpieczeństwa na obszarze woj. pomorskiego [Ecological basis for development and security in the Pomerania Province], mscr.

Czochański J.T., 2004, Koncepcja zachowania sieci ekologicznej w województwie pomorskim jako podstawy rozwoju przestrzennego regionu [The concept on preservation of the ecological network in the Pomeranian Region as a fundament for regional spatial development], [in:]
A. Cieszewska (ed.), Płaty i korytarze jako elementy struktury krajobrazu - możliwości i ograniczenia koncepcji [Patches and corridors as a landscape elements adventages and limitations of the concept]. Problemy Ekologii Krajobrazu, SGGW, Warszawa: 84-92.

Dombrowski A., Głowacki Z., Kovalchuk I., Nikiforov M., Michalczyk Z., Szwajgier W. \& Wojciechowski K.H., (eds), 2002, Bug river valley as the ecological corridor: state - threats - protection. Foundation IUCN Poland, Warsaw.

Forman R.T.T. \& Godron M., 1981, Patches and Structural Components for A Landscape Ecology. BioScience 31(10): 733-740.

Gallé L., Margóczi K., Kovács É., Györffy Gy., Körmöczi L. \& Németh L., 1995, River valleys: Are they ecological corridors? Tiscia 29, 53-58.

Jędrzejewski W., Nowak S., Stachura K., Skierczyński M., Mysłajek R.W., Niedziałkowski K., Jędrzejewska B., Wójcik J.M., Zalewska H. \& Pilot M., 2005, Projekt korytarzy ekologicznych łączących Europejską Sieć Natura 2000 w Polsce [Project of ecological corridors connecting the European network Natura 2000 in Poland]. Zakład Badania Ssaków PAN, Białowieża.

Jongman R. \& Kamphorst D., 2002, Ecological corridors in land use planning and development policies. Council of Europe Publishing, Strasbourg.

Kałamucka W., 2007, Ochrona dolin rzecznych w systemie obszarów chronionych na przykładzie województwa lubelskiego [Protection of river valleys in the protected areas system on the example of Lubelskie region]. Czasopismo Techniczne 7: 239-245.

Koncepcja Przestrzennego Zagospodarowania Kraju 2030 [National Spatial Development Concept 2030], dokument przyjęty przez Radę Ministrów 13 grudnia 2011 r., Warszawa.

Liro A. (ed.), 1995, Koncepcja krajowej sieci ekologicznej ECONET - Polska [National Ecological Network ECONET - Poland]. Fundacja IUCN Poland, Warszawa.

Pchałek M., Kupczyk P., Matyjasiak P. \& Juchnik A., 2011, Efektywność ochrony korytarzy ekologicznych. Koncepcja zmian legislacyjnych [The effectiveness of the protection of ecological corridors. The concept of legislative changes]. WWF Polska, Agencja Wydawnicza EkoPress, Warszawa.

Pietrzak M., 2010, Podstawy i zastosowania ekologii krajobrazu. Teoria i metodologia [Fundamentals and applications of landscape ecology. Theory and methodology]. Wydawnictwo Uczelniane Państwowej Wyższej Szkoły Zawodowej im. J.A. Komeńskiego w Lesznie, Leszno.

Plit J., 2007, Ewolucja krajobrazów kulturowych dolin rzecznych na ziemiach polskich [Evolution of cultural 
landscapes of river valleys on Polish territory]. Prace Komisji Krajobrazu Kulturowego 7: 28-40.

Plit J., 2008, Zarządzanie krajobrazem dolin rzecznych [Managing the river valley landscape]. Prace Komisji Krajobrazu Kulturowego 10: 230-240.

Przewoźniak M., 2001, Strukturalizacja przyrodnicza obszaru woj. pomorskiego oraz opis i waloryzacja jednostek strukturalno-funkcjonalnych [Natural ecological structure of the Pomerania Province and the description and valorisation of the structural and functional units], mscr.

Romanowski J., 2007, Vistula River Valley as the ecological corridor for mammals. Polish Journal of Ecology 55(4): 805-819.

Rozenau-Rybowicz A. \& Baranowska-Janota M., 2007, Korytarze ekologiczne w planowaniu przestrzennym [Ecological corridors in spatial planning]. Problemy Rozwoju Miast 4(1-2): 132-142.
Ustawa z dnia 16 kwietnia 2004 r. o ochronie przyrody [Dz. U. 2016 poz. 2134 ze zm., Kancelaria Rady Ministrów] [The Act of 16 April 2004 on the Nature Conservation (Journal of Laws of 2016, item 2134, as amended) Chancellery of the Prime Minister, Warszawa].

Walker R. \& Craighead L., 1997, Analyzing wildlife movement corridors in Montana using GIS. Proceedings International ESRI Users Conference, Redlands, California: 8-11.

Wojciechowski K., 2004, Wdrażanie idei korytarzy ekologicznych [Implementation of ecological corridors concept], [in:] A. Cieszewska (ed.), Płaty i korytarze jako elementy struktury krajobrazu - możliwości i ograniczenia koncepcji [Patches and corridors as a landscape elements - adventages and limitations of the concept]. Problemy Ekologii Krajobrazu, SGGW, Warszawa: 221-228. 